\title{
Performance Comparison of Mutual Funds and Sharia Mutual Funds
}

Kharisma Novita Sari ${ }^{1 *}$, Moch Sulchan ${ }^{2}$, Mimah Mutamimah ${ }^{3}$

Faculty of Economics and Islamic Business, UIN Sayyid Ali Rahmatullah Tulungagung, Tulungagung ${ }^{1,2,3}$

fkharismansari@yahoo.co.id ${ }^{1 *}$, sulkhanmoch@gmail.com ${ }^{2}$, mutamimah@gmail.com $^{3}$

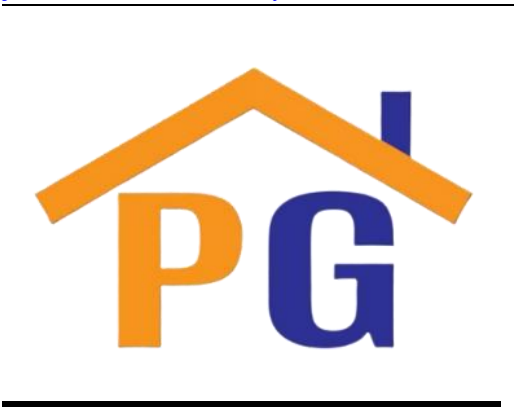

Riwayat Artikel

Diterima pada 26 Juli 2021

Direvisi pada 2 September 2021

Disetujui pada 7 September 2021

\begin{abstract}
Purpose: This study aimed to examine the differences in the performance of Islamic mutual funds with mutual funds based on the Sharpe and Jensen method for the 2010-2020 period in the Indonesian Capital Market.
\end{abstract}

Research Methodology: The study uses a quantitative approach to the type of comparative research. The data used is secondary data from OJK. The population used in this study is the capitalization of sharia mutual fund performance data with mutual funds, the period 2010-2020 (monthly data) in the Indonesian Capital Market. Data analysis was carried out using the Sharpe and Jensen method and the Manova test with the help of the SPSS statistical program.

Results: The results of this study indicate that there is no significant difference between the performance of Islamic mutual funds and mutual funds with the Sharpe and Jensen method. This shows that the return on the performance of Islamic mutual funds and mutual funds based on the Sharpe and Jensen method received will be relatively the same. Investment performance in Mutual Fund portfolio management is reflected in the net asset value (NAV).

Limitations: This research has been attempted and carried out in accordance with scientific procedures. However, it still has limitations; this research is limited to $2010-2020$ with monthly data.

Contribution: This research implies that this research can better contribute to the general public, academics, and investors to understand the performance of capital market investment instruments before they invest.

Keywords: Performance, Mutual Funds, Sharia Mutual Funds, Sharpe and Jensen Methods

How to Cite: Sari, K. N., Sulchan, M., \& Mutamimah, M. (2021). Performance comparison of mutual funds and sharia mutual funds. Bukhori: Kajian Ekonomi dan Keuangan Islam, 1(1), 65-77.

\section{Introduction}

Indonesia is a country with a large capital market performance in growing the sharia-based and conventional financial industry. Sharia-based and conventional investments in the capital market have the aim of developing finance in Indonesia. For now, especially during the COVID-19 pandemic, sharia-based and conventional investment activities have begun to decline. It turned out that in an increase, the development of the world economy also declined due to COVID-19, including the country of Indonesia. During the first Quarter of 2020, Indonesia has quite a record of economic growth from 2.97 percent. Data on the realization of investment realization in the first quarter Investment performance is an activity return portfolio of investment activities. The investment activity portfolio contains one or more assets. Investment performance is calculated over a certain period as well as in a certain currency (BKPM, 2021). Investors often compare different 
types of returns. The difference between the total of returns as well as price, which one is the first to assess the income flower but the second only assesses the appreciation of the capital.

The next sharia investment instrument is that Mutual Funds are created and created as a tool in collecting public funds that already have much capital, have hope in carrying out investment activities, but have enough time and limited understanding. The public initially knew Sharia Mutual Funds in Indonesia in 1997, where there was a sign of the issuance of the Sharia Mutual Fund Danareksa Saham in July 1997. Being part of an investment instrument, Sharia Mutual Funds have special characteristics that are certainly different from conventional ones in general. The differences are shown from the instruments in investing and investment procedures that are not permitted to be contrary to sharia-based principles. In addition, there are differences shown that all portfolio management processes. Mutual funds are a solution in investment activities for investors, especially small-scale investors and investors who do not have enough time or ability to assess the risk of investment activities that have been carried out. Mutual funds are also created or designed to collect money or funds from people who have sufficient capital, have hope in carrying out investment activities but have sufficient time and very limited understanding. Mutual funds are also expected to be able to increase the role of local investors in carrying out investment activities in the Indonesian capital market.

So far, Mutual Funds as a forum for associations that are used to collect funds from the public are investors, which will then be invested through a securities portfolio carried out by Investment Managers. According to the Capital Market Law, Number eight of 1995, article one paragraph 27, Mutual Funds are a forum for associations used to collect funds originating from the investor community, which are then invested in securities portfolios by investment managers. The following funds are managed in securities portfolio investments, and finally, funds are managed by investment information regarding the above understanding is that there are funds originating from the investorsfurthermore, managers. Funds originating from and existing in Mutual Funds become mutual funds with investors. The researchers discuss this research because we want to examine the performance of sharia and conventional instruments before and during the covid-19 pandemic, wherein the first quarter of 2020, the or asset classes are added to a portfolio. The higher the Sharpe Ratio value, the better the performance of an Indonesian Capital Market instrument. Furthermore, the researcher chose the Jensen method on the grounds that this method does not indicate the same performance in the future. Bareksa (2019) Indonesia only has a record growth of 2.97 percent in the economy. Researchers chose sharia mutual fund products compared to mutual funds on the grounds that these products experienced rapid growth pretty good in the last five years. Growth The economic conditions that occur in this investment activity can be seen from the NAV. (Bareksa, 2021)

The researchers chose the Sharpe method because it is the most widely used method for calculating risk-adjusted returns on investments and is often used to compare changes in overall risk-return characteristics when new assets or asset classes are added to a portfolio. The higher the Sharpe Ratio value, the better the performance of an Indonesian Capital Market instrument. Furthermore, the researchers chose the Jensen method on the grounds that this method does not indicate the same performance in the future (Bareksa, 2019).

\section{Literature review}

\section{Theory description}

1. Portfolio Performance

a. Sharpe Performance Measure

Assessment of the size of Sharpe's Performance is the method used in distinguishing a portfolio's performance. Sharpe tries to formulate a series of portfolio activity performance whose value can be measured as a net result from portfolio activities. Sp can symbolize the risk-free interest rate per unit of risk. The following formula can measure this performance index:

$\mathrm{Sp}=\frac{R p-R f}{\sigma p}$ 
Information:

$-\mathrm{Sp}=$ index of Sharpe's performance.

$-\mathrm{Rp}=$ return from portfolio.

$-\mathrm{Rf}=$ return free from risk interest rate free from risk.

$-\sigma p=$ total risk derived from the addition of systematic and unsystematic risks.

b. Jensen Performance Measure Kinerja

Jensen is an index that is useful in assessing a difference between the actual rate of return obtained by the portfolio. The Jensen index is easier to express in terms of how much the portfolio "beats the market." The index can have a positive value meaning the portfolio provides a return greater than the expected return. It is a good thing because the portfolio has a relatively high return for its systematic level. (Tandelilin, 2011) ${ }^{\mathrm{i}}$ The following formula can measure Jensen's performance index:

$J=R p-[R f+(R p-R f) \beta]$

Information:

- = index of Jensen's performance. $J$

$-\mathrm{Rp}=$ return from portfolio

$-\mathrm{Rf}=$ risk-free return, risk-free interest rate.

$-\beta=$ portfolio beta

\section{Mutual Fund}

In Law 8 of 1995 Article 1 paragraph 27 relating to the capital market, mutual funds are a forum to collect financial funds from the public to be included in securities portfolio investments that managers in investment activities will carry out. (Mustofa, 2017)

The characteristics of mutual funds are:

a. A collection of owner funds, where a mutual fund owner is a person who invests his money with various variations, meaning that mutual funds can be carried out individually or by institutions, where the party invests in mutual funds according to the purpose of the investment.

b. Funds are invested in securities known as investment instruments.

c. Mutual funds are managed by Investment Managers.

So that with the existence of mutual funds, the community can surrender its duties. Mutual funds have predicted and observed stocks to have a good prospectus and can provide profitable value because they are managed by investment advisors in their fields. Mutual funds are related to the stock exchange because mutual funds are tools for investing that have the aim of helping investors enter their capital in a company that is an issuer. The presence of mutual funds can reduce the risk resulting from stock investment because investment advisors will have predictive potential in seeing the stocks they choose. Mutual funds in Indonesia were originally in 1995, with the birth of corporate mutual funds in the field of PT. BDNI Mutual Funds. Benefits to investors, namely:

a. To access investment instruments that are difficult to implement alone

b. The management is carried out by investment managers who already have experience and investment administration is carried out by the Custodian Bank.

c. Diversification of investments that are difficult to carry out alone due to limited funds or finances

d. Mutual fund investment results are not included in the tax object

e. The liquidity is high because the Participation Units can be purchased and withdrawn every day

f. The investment funds needed are relatively small, starting from Rp. 200.000,- someone can already invest

The elements of the Mutual Fund are:

a. Manager

Its management consists of investment managers and custodian banks. An investment manager is a company whose business activities manage a portfolio of securities owned by customers and is responsible for the investment. Meanwhile, the custodian bank acts as a repository of wealth. The custodian bank is responsible for carrying out investment administration activities, including 
transaction settlement, registration, and securities registration. So the funds owned by mutual funds belong to investors and are stored in custodial banks.

b. Legal Form

In Indonesia, there are two legal forms of mutual funds, namely in the form of a Limited Liability

Company and a Collective Investment Contract. The PT will issue shares that investors can purchase.

Meanwhile, Collective Investment Contract mutual funds issue participation units. Mutual funds are distinguished by their operational nature, namely open and closed mutual funds.

c. Investment Placement, Proof of Ownership, and Investment Return

Investment in mutual funds is by purchasing shares or participation units issued by mutual funds. Units of participation can be assumed to be like units of company shares. The price per unit of participation is measured based on the Net Asset Value (NAV/unit of participation) generated by the custodian bank every day and reported in daily newspapers. For proof of ownership of the participation unit, the bank will provide a confirmation letter of ownership of the participation unit. Some mutual funds do not send confirmation letters but issue or print monthly reports, which are also useful for proof of ownership of the participation unit.

d. Mutual Fund Fees and Taxes

Open-ended mutual fund investors must pay attention to the costs provided directly and indirectly. Direct costs are given to investors in the form of purchase fees charged when purchasing the investment units and resale costs charged when investors resell their investment units. Indirect costs provided to investors consist of investment manager fees, custodian bank fees, transaction fees, auditor fees, and tax costs directly related to investment management. These costs are said to be indirect because they are not immediately focused on investors.

Table 1. Differences between Sharia Mutual Funds and Mutual Funds

\begin{tabular}{|c|c|}
\hline \multicolumn{2}{|c|}{ Mutual Fund } \\
\hline Sharia Mutual Funds & Mutual Fund \\
\hline Managed according to sharia principles & $\begin{array}{c}\text { Managed without paying attention to } \\
\text { sharia principles }\end{array}$ \\
\hline $\begin{array}{c}\text { Investments only in sharia securities are } \\
\text { allowed }\end{array}$ & $\begin{array}{c}\text { Investment in all allowed securities } \\
\text { halal assets }\end{array}$ \\
$\begin{array}{c}\text { There is a mechanism for cleaning non- } \\
\text { Do not use the concept of cleaning } \\
\text { non-halal property }\end{array}$ \\
\hline There is a Sharia Supervisory Board & There is no Sharia Supervisory Board \\
\hline
\end{tabular}

\section{Previous Studies}

Source:_(Malik, 2021)

Research that supports the performance of sharia mutual funds vs. mutual funds is research conducted by Purwanto by analyzing the performance of Islamic stock mutual funds using the Sharpe, Treynor, Jensen, $\mathrm{M}^{2}$, and TT methods. The result is that there are no sharia-based equity mutual funds that perform positively (Nur Kholidah, 2019). Research that supports the performance of sharia mutual funds vs. mutual funds is research conducted by Lestari (Lestari, 2015) by looking at the performance of Islamic stock mutual funds and conventional stock mutual funds. The results showed that the performance of conventional stock mutual funds was superior to the performance of Islamic stock mutual funds based on the Sharpe rv/s method of 11,900. (Lestari, 2015) The difference between this study and research from Sustainable is using the Sharpe method, while this study uses the Sharpe and Jensen method.

\section{Research methodology Research Design}

This study uses a quantitative approach because this study emphasizes testing theories through the assessment of research variables with numbers according to statistical procedures (Sugiyono, 2014). While this type of research uses the type of comparative research. Comparative research is comparative research. Comparative research is comparing the existence of a variable or more in two or more different samples or at different times. 


\section{Research Variable}

In a study, there are research variables that are commonly referred to as variables $\mathrm{X}$ and $\mathrm{Y}$ variables. The independent variable is a variable that is deliberately manipulated to know its intensity or its effect on the independent (bound) variable. It can also be interpreted that the independent variable is a variable that affects other variables. (Iqbal, 2013) While the dependent variable (independent) is a variable where the variable arises as a result of the independent variable. Or it can be said that the dependent variable arises because there is an influence or response from the dependent variable or what is commonly called the independent variable. In this study, the independent variable is Mutual Funds VS Sharia Mutual Funds

\section{Population, Sample Technique, and Research Sample Population}

The population is an area of generalization consisting of objects and subjects with quality grades carried out by researchers to conclude. The population used in this study is the capitalization of sharia mutual fund performance data and mutual funds using the Sharpe, Jensen method for the period 20102020 (monthly data) in the Indonesian Capital Market.

Sampling Technique

In this study, a non-probability sampling technique was used because the sample was found in monthly data related to its performance. Non-probability sampling is used in taking a sample that does not provide an opportunity for every element of the existing population.

Sample

The sample is part of the additional characteristics possessed by the population. The sample in this study is the performance data of sharia mutual funds and mutual funds, using the Sharpe, Jensen method for the period 2010-2020 (monthly data) in the Indonesian Capital Market. Thus, the final result of the amount of data studied as research samples amounted to $11 \times 12=132$ samples in each independent variable.

\section{Research Instruments}

The research instrument is a tool to assess the natural and social phenomena under study. A research instrument is a tool or a facility used by a researcher to conduct research or research. This is useful for obtaining better, more accurate, complete, or more accurate results so that the data is easy to process and easy to analyze. In other books also explained the meaning of the instrument. It is explained that a research instrument is a tool or facility used by a researcher to collect the data needed in research in order to obtain complete, accurate data so that data processing is easier.

\section{Sources and Data Collection Techniques}

\section{Data Source}

Data is a raw material that needs to be processed so that it can produce information or a description, both quantitative and qualitative data that shows facts. Data sources are divided into 2, namely: (1) primary data; (2) secondary data. In this study, researchers used secondary data sources from official websites or websites related to the studied variables. Secondary data is data collected beforehand or published by the relevant agencies so that the data can be obtained from the official website or from the accounting information of a company being studied. Meanwhile, for the time of data collection, in this study, researchers used time-series data taken in monthly form over 11 years.

\section{Data Collection Technique}

Data collection technique is a technique or a method used by researchers to collect data in order to test data. Data collection includes things that simplify things, then compile them into data that is easy to understand. Whether it's data in numeric form or data in categorical form (Reksoatmodjo, 2019).

a. Observation technique

The observation method is a method that is carried out in order to observe the object of research. The observation technique is carried out to explore data or information that is the observational and systematic recording of the object being studied. Research observation can be done directly or indirectly. In connection with this study, researchers used indirect observation of the object of 
research being studied, namely, indirect observation through official website visits, news and information related to the object of this research.

b. Literature study

A literature study is research-based on library theory based on understanding or theory derived from the study of books and so on. Use it as a reference material that may be needed when conducting research. Literature study includes matters related to theoretical research object information. Both are related to the understanding of research variables and other things that may be needed, especially in order to examine theoretical knowledge of the variables being studied. Data collection techniques are carried out in the form of documentation. Documentation is secondary data stored in the form of files (conventional and electronic records), books, writings, etc.

\section{Data analysis}

Sharpe method

$\mathrm{Sp}=\frac{R p-R f}{\sigma p}$

Information:

$-\mathrm{Sp}=$ index of Sharpe's performance.

$-\mathrm{Rp}=$ return from portfolio.

$-\mathrm{Rf}=$ return free from risk interest rate free from risk.

$-\sigma p=$ Standard deviation.

b. Jensen method

$J=R p-[R f+(R p-R f) \beta]$

Information:

- = index of Jensen's performance. $J$

$-\mathrm{Rp}=$ return from portfolio

$-\mathrm{Rf}=$ risk-free return, risk-free interest rate.

$-\beta=$ portfolio beta

After assessing the data, the next step is to analyze the data statistically using the SPSS program. Here's the analysis:

\section{Classic assumption test}

1. Normality

Normality serves to indicate that the existing data is normally or not normally distributed. Graph analysis and statistical test (Kolmogorov-Smirnov test) indicates the distribution. The data must be normally distributed if it goes into parametric analysis. The reference for making a decision is using the Kolmogorov-Smirnov test by comparing significance with the magnitude, if the significance > then the data is normally distributed. When the skewness and kurtosis ratio is between -2 and 2 , then the assumption of normality shows that it is fulfilled. And vice versa. Because the data used in this study for each variable amounted to more than $30(n \geq 30)$, the data were considered normal and could be analyzed using the Kolmogorov-Smirnov test.

\section{Multicollinearity test}

The multicollinearity test can arise due to causality between two or more dependent variables and the fact that two or more explanatory variables are simultaneously influenced by a third variable outside the model. To find out the multicollinearity of a study, it is necessary to pay attention to the VIF (variance inflation factor) value of less than 10 , so it can be said that the test avoids multicollinearity. In a test, it is hoped that the tested data will avoid multicollinearity.

\section{Heteroscedasticity test}

Multiple regression models that meet the requirements have the same variance from one test residual with the other tests being fixed. Or it can be called homoscedasticity so that a good test is a test that avoids heteroscedasticity. This can be indicated by the presence of: (1) the distribution of the points of 
the object of observation does not form a certain pattern (avoiding the pattern); (2) the points spread between, above, or below the centerline or can also be called point coordinates 0 ; (3) the points do not collect in certain parts, such as only below, or only above.

\section{Autocorrelation Test}

An autocorrelation test is a correlation test that occurs between objects under study where the objects are located sequentially or in a row. Usually, this happens in a futures test such as time-series data. The correlation itself is a structured analysis to partially determine the strength of a relationship between one variable and another research variable.

\section{a. Homogeneity Test (Similarity of Variety)}

This homogeneity test was carried out using the F test (Levene's Test) to determine whether the variance of the two values was the same or different. The homogeneity test hypothesis is as follows:

b. Hypothesis testing

Hypothesis testing is a temporary answer to a problem that may be considered true and temporary because it requires proof first. The hypothesis is basically a temporary conjecture that is considered the most correct, which is based on logical thinking and uses the knowledge window as a means of supporting it. In comparison, hypothesis testing is an action taken by the examiner through certain procedures and stages regarding the provisional assumption, which ultimately gives an answer to the examiner accepting or rejecting a hypothesis. In this study, to test a hypothesis, the researcher used the following test.

In Univariate Analysis of Variance, the decision results are generated according to one test statistic, namely the $\mathrm{F}$ test, which has a value determined by the result of dividing by 2 the average addition of the squared value, for the estimated magnitude of the distribution of the estimated magnitude of the related variable. The Multivariate Analysis of Variance has test statistics that can be used to produce decisions, including:

1) Pillai's Trace. The test statistics are used on the assumption that the homogeneity of the values of the variance-covariance matrix has not been met, the sample size is small, and the results of the tests are contrary to the others, namely when there are most of the vector quantities that have opposite average values, but others are not opposite. The greater the value of Pillai's Trace statistical test, the greater the influence on the model or method.

2) Wilk's Lambda. The test statistics were used on more than 2 groups of independent variables and the assumption about the homogeneity of the variance-covariance matrix values was fulfilled. The smaller the value of Wilk's Lambda statistical test, the greater the influence on the model or method. The Wilk's Lambda quantity is between zero and one.

3) Hotelling's Trace. This test statistic was applied to 2 groups of independent variables. The greater the value of the Hotelling's Trace statistical test, the greater the influence on the model or method.

4) Roy's Largest Root. The test statistic is used on the assumption that the variance-covariance homogeneity is satisfied.

\section{Manova Test}

The Manova test is a generalization of the analysis of variance for situations where there are several independent variables by measuring several dependent variables. Researchers can increase the likelihood of changes resulting from different treatments and different interactions but increase the complexity of the analysis. The advantage of MANOVA over a series of ANOVA for each dependent variable is protection against type 1 error. However, this advantage will be seen only when a twotailed significance test is performed. However, if a one-sided test is desired, the use of MANOVA may result in an unacceptable loss of results.

Like the ANOVA test, the MANOVA test is a test related to different variances. In ANOVA, the variance being compared comes from a related variable, while in MANOVA, the variance being compared comes from more than one related variable. This research will use SPSS 16.0 For Windows. 


\section{Results and Discussion}

\section{Data Analysis of Sharia Mutual Funds VS Mutual Funds}

Normality test

Normality testing is carried out to see the variables used are normally distributed or not. The way to test for normality is the Kolmogorov-Smirnov test, with the following results:

Table 2. Kolmogorov-Smirnov . Normality Test

\begin{tabular}{|c|c|}
\hline & $\begin{array}{c}\text { Unstandardize } \\
\mathrm{d} \text { Residual }\end{array}$ \\
\hline asymp. Sig. & .125 \\
\hline
\end{tabular}

(Source: SPSS 16 Output Results)

Based on the table, the asymp. Sig. (2-tailed) sig value is 0.125 , so it can be said that the data used in this study is normally distributed. Other normality tests can also show the results of the data being normally distributed or not. Namely by using the PP Plot test as follows:

Figure 1. PP Plot Normality Test Results

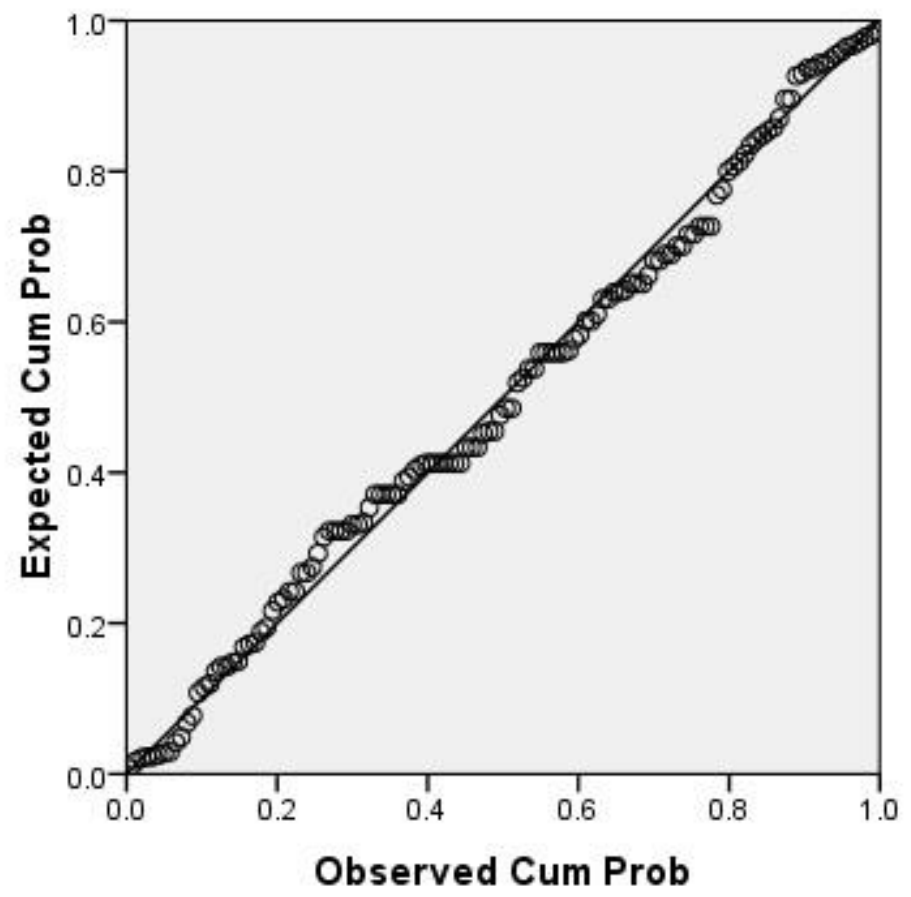

Source: SPSS Output Results

In the normality of the data with the Normal PP Plot (Figure 1), the data on the variables used are declared normal or close to normal. Variables are called normal when the SPSS distribution image is accompanied by data value points that are located spread around a diagonal line and the points spread on the data in the same direction following a diagonal line. Thus, based on the Normal PP Plot image above, the data used is declared to be normally distributed. 
Figure 2. Histogram normality test results

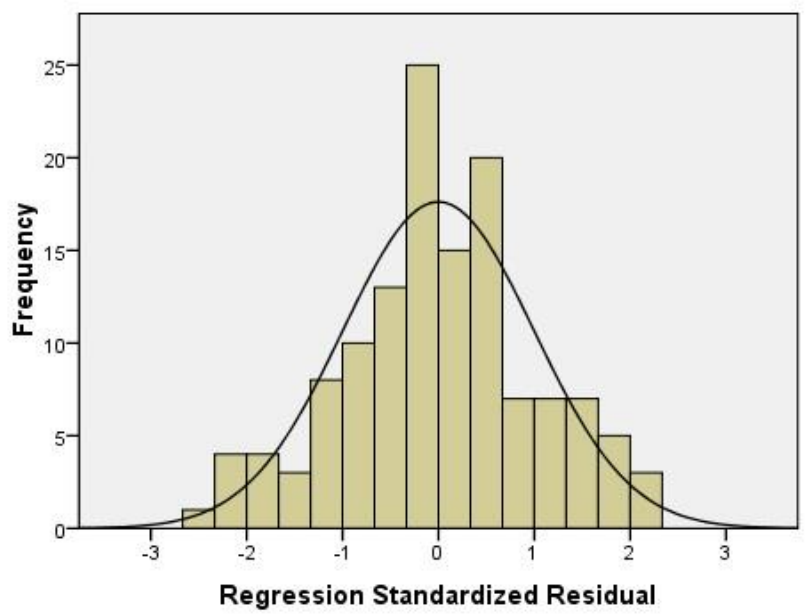

Source: SPSS Output Results

Based on Figure 2 histogram normality test above, it can be seen that the shape is like a bell. So, based on the histogram image above, the data used is declared to be normally distributed.

\section{Homogeneity Test}

This homogeneity test was carried out using the F test (Levene's Test) to determine whether the variance of the two values was the same or different. If there is no significant difference between the two variances, use the variance to compare the population mean/test for Equality of Means using a ttest on Equal Variance Assumed. And suppose there is a significant difference between the two variances, making use of the variance to compare the population mean with a t-test. In that case, it is better to use it on the basis of Equal Variance Not Assumed. Ways to test for homogeneity, with the following results:

Table 3. Homogeneity Test

\begin{tabular}{|c|c|c|}
\hline & Levene Statistics & Sig. \\
\hline MUTUAL & 2.279 & .132 \\
FUND_SHARIA & 3,545 & .061 \\
MUTUAL FUND & & \\
\hline
\end{tabular}

(Source: SPSS 16 Output Results)

Based on the table value of sig. for sharia mutual funds is 0.132 and mutual funds is 0.061 , so $\mathrm{H} 0$ is accepted, and it can be said that based on the Sharpe and Jensen method for the 2010-2020 period, the performance of sharia mutual funds and mutual funds has the same variance.>

\section{Classical Assumption Test}

The classical assumption needs to be done to ensure that the data under study is properly protected or protected from multicollinearity, heteroscedasticity and autocorrelation so that the resulting data can be processed and analyzed in the next stage according to the data analysis stage in this study.

1. Multicollinearity Test

Research that uses multiple regression analysis techniques between independent variables should not be correlated with each other, or multicorrelation occurs. Detection of the non-occurrence of multicorrelation can be seen in the collinearity statistic, provided that if the tolerance value of each independent variable is above 0.1 , The results of the multicollinearity test can be seen as follows:

Table 4. Multicollinearity Test Results

\begin{tabular}{|l|l|l|}
\hline \multirow{2}{*}{ Model } & \multicolumn{2}{|c|}{ Collinearity } \\
\cline { 2 - 3 } & Tolerance & VIF \\
\hline 1 & & \\
\hline
\end{tabular}




\begin{tabular}{|l|l|l|l|}
\hline & mutual funds & 1,000 & 1,000 \\
\hline 2 & Sharia mutual funds & 1,000 & 1,000 \\
\hline
\end{tabular}

Source: SPSS Output Results (processed)

From the results of the multicollinearity test in Table 4, which was carried out on the research variables, there were no symptoms of multicollinearity because it is known that the value of the variance inflation factor (VIF) is 1,000 bonds and 1,000 Sukuk.

\section{Heteroscedasticity Test}

To test whether or not there is a problem with heteroscedasticity, namely using a scatterplot graph, the graph forms a special image pattern, so the model can be said to have heteroscedasticity. The results of the heteroscedasticity test are as follows:

Figure 3. Heteroscedasticity Test Results

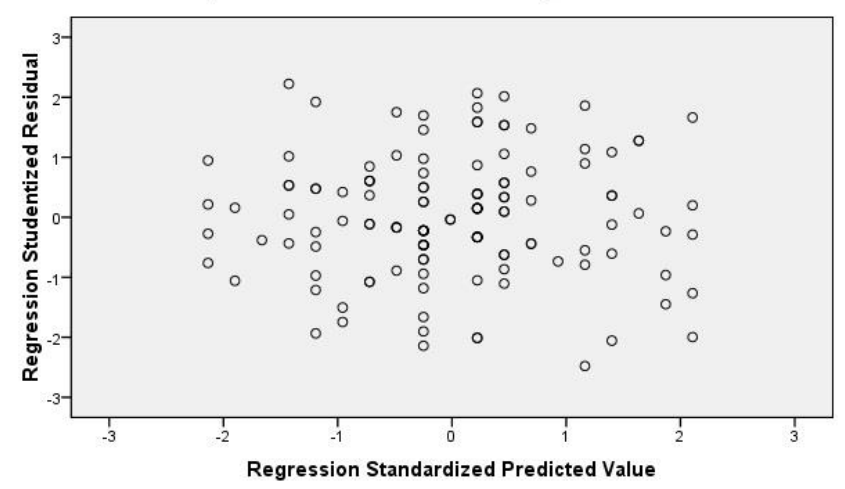

Source: SPSS 2021 Output Results

Based on the scatterplot graph, there is no heteroscedasticity.

Table 5. Heteroscedasticity Test Results

\begin{tabular}{|c|c|}
\hline Model & Sig. \\
\hline $\begin{array}{c}1 \text { (Consta } \\
n t)\end{array}$ & .675 \\
\hline $\begin{array}{c}\text { Sharia } \\
\text { mutual } \\
\text { funds }\end{array}$ & .060 \\
\hline $\begin{array}{l}2 \text { mutual } \\
\text { funds }\end{array}$ & .092 \\
\hline
\end{tabular}

Source: SPSS 2021 Output Results (processed)

Based on the table of the Glejser test above shows that the significant value has a value above 0.05 . This can be seen from the sig value above for Islamic mutual funds that have a value of $0.060>0.05$ and mutual funds $0.092>0.05$. With the results of the Glejser test above, it can be seen that the data is free from heteroscedasticity symptoms. So that testing can be carried out to the next stage

\section{Autocorrelation Test}

This test is carried out to test whether there is a relationship between members of the observation located in a row. In order to test the presence of autocorrelation, the Durbin Watson or DW test can be used, provided that less than DW is less than 4-DU, then there is no autocorrelation. The following is the autocorrelation test: 
Table 6. Autocorrelation Test Results

\begin{tabular}{|c|c|c|c|c|c|}
\hline Model & $\mathrm{R}$ & R Square & $\begin{array}{c}\text { Adjusted R } \\
\text { Square }\end{array}$ & $\begin{array}{c}\text { Std. Error of } \\
\text { the Estimate }\end{array}$ & Durbin-Watson \\
\hline 1 & $.852 \mathrm{a}$ & .725 & .723 & 66862.18220 & 1.047 \\
\hline
\end{tabular}

Source: SPSS 2021 Output Results (processed)

From the test results using the Durbin-Watson test above, the Durbin Watson value is 1.047 , so it can be concluded that there is no autocorrelation.

Hypothesis Testing

Test the hypothesis using Pillai's Trace, Wilks' Lambda, Hotelling's Trace and Roy's Largest Root. The researcher can increase the likelihood of changes resulting from different treatments and interactions but increase the complexity of the analysis. How to test with the following results:

Table 7. Multivariate Tests

\begin{tabular}{|c|c|c|}
\hline \multicolumn{2}{|r|}{ Effect } & Sig. \\
\hline METHOD & Pillai's Trace & .015 \\
\hline & Wilks' Lambda & .015 \\
\hline & Hotelling's Trace & .015 \\
\hline & $\begin{array}{c}\text { Roy's Largest } \\
\text { Root }\end{array}$ & .015 \\
\hline
\end{tabular}

(Source: SPSS 16 Output Results)

Based on the value of the test results Pillai's Trace of 0.040 indicates the effect of the method is getting smaller, Wilks' Lambda of 0.960 indicates the effect of the method is getting bigger. Hotelling's Trace of 0.040 indicates the method is getting smaller and Roy's Largest Root of 0.040 indicates the method is getting smaller. It can be concluded that there is no significant difference in the performance of mutual funds and sharia mutual funds using the Sharpe and Jensen method ( $\mathrm{H} 0=$ rejected and $\mathrm{H} 1=$ accepted).

Table 8. Manova Test - Pairwise Comparison

\begin{tabular}{|c|c|c|c|c|c|}
\hline $\begin{array}{l}\text { Dependent } \\
\text { Variable }\end{array}$ & $\begin{array}{c}(\mathrm{I}) \\
\text { METHO } \\
\text { D }\end{array}$ & $\begin{array}{c}(\mathrm{J}) \\
\text { METHOD }\end{array}$ & $\begin{array}{c}\text { Mean } \\
\text { Difference (IJ) }\end{array}$ & $\begin{array}{l}\text { Std. } \\
\text { Error }\end{array}$ & Sig.a \\
\hline \multirow{2}{*}{$\begin{array}{c}\text { MUTUAL } \\
\text { FUND_SH } \\
\text { ARIA }\end{array}$} & $\begin{array}{l}\text { SHARP } \\
\text { E }\end{array}$ & JENSEN & .894 & .496 & .073 \\
\hline & $\begin{array}{l}\text { JENSE } \\
\mathrm{N}\end{array}$ & SHARPE & -.894 & .496 & .073 \\
\hline \multirow[t]{2}{*}{$\begin{array}{l}\text { MUTUAL } \\
\text { FUND }\end{array}$} & $\begin{array}{c}\text { SHARP } \\
\text { E }\end{array}$ & JENSEN & $1,485^{*}$ & .486 & .063 \\
\hline & $\begin{array}{l}\text { JENSE } \\
\mathrm{N}\end{array}$ & SHARPE & $-1.485^{*}$ & .486 & .063 \\
\hline
\end{tabular}

(Source: SPSS 16 Output Results)

Based on the results of the Manova test in the table above, it shows that for the Islamic mutual fund variable when compared to Sharpe and Jensen, there is no significant difference because of the value 
of sig. both are greater than 0.05 , which is 0.115 . Furthermore, for the mutual fund variable, when compared with the Sharpe and Jensen methods, there is no significant difference because of the sig values both are greater than 0.05 , which is equal to 0.063 . So partially for sharia mutual funds and mutual funds, the results are $\mathrm{H} 0=$ rejected and $\mathrm{H} 1=$ accepted 1

\section{Discussion}

The results of the hypothesis test of this study indicate that $\mathrm{H} 0$ is rejected and $\mathrm{H} 1$ is accepted because the significance value is less than 0.05 , so that this study shows that there is no significant difference between the performance of Islamic mutual funds and mutual funds. Sharia mutual funds and mutual funds as a forum for collecting funds from the public will be managed by a legal entity, namely the Investment Manager.

This research is supported by the research of Purwanto in(Nur Kholidah (2019) by analyzing the performance of Islamic stock mutual funds using the Sharpe, Treynor, Jensen, $\mathrm{M}^{2}$, and TT methods. The result is that there are no sharia-based equity mutual funds that perform positively. The results of the study using the method of Sharpe, Treynor, and Jensen showed no significant difference.Research that supports the performance of sharia mutual funds vs mutual funds is research conducted by Lestari (Lestari, 2015) by looking at the performance of Islamic stock mutual funds and conventional stock mutual funds. The results showed that the performance of conventional stock mutual funds was superior to the performance of Islamic stock mutual funds based on the Sharpe rv/s method of 11,900. The results show that there is no significant difference. The differences between this study and research from Sustainable is using the Sharpe method while this study uses the Sharpe and Jensen method. Investment performance in Mutual Fund portfolio management is reflected in the net asset value (NAV). Whether or not the investment portfolio's performance managed by the investment manager is influenced by the policies and investment strategies undertaken. Therefore, in order to know the development of the investment value of a mutual fund, it can be seen from the increase in the value of its net assets, which is also the investment value of the investor.

Therefore, the results of this study's hypothesis test indicate that $\mathrm{HO}$ is rejected and $\mathrm{H} 1$ is accepted so that the performance of Islamic mutual funds with Sharpe and Jensen methods is no significant different. Where this research supports previous research and is strengthened by theory. This shows that the return on Islamic mutual funds and mutual funds based on the Sharpe and Jensen methods that will be received will be relatively the same. Investment performance in Mutual Fund portfolio management is reflected in the net asset value (NAV). Whether or not the policies and investment strategies influence the performance of the investment portfolio managed by the investment manager undertaken

\section{Conclusion}

The results of this study indicate no significant difference in the performance of sharia mutual funds and mutual funds with the Sharpe and Jensen methods. This is indicated by H1, which is tested and accepted in the second hypothesis. This shows that the return on the performance of Islamic mutual funds and mutual funds based on the Sharpe and Jensen method that will be received will be relatively the same. Investment performance in Mutual Fund portfolio management is reflected in the net asset value (NAV). Whether or not the investment portfolio's performance managed by the investment manager is influenced by the policies and investment strategies undertaken.

\section{Limitations and study forward}

This research has been attempted and carried out in accordance with scientific procedures; however, it still has limitations. Namely this research is only limited to $2010-2020$ with monthly data, so a longer period is needed with a wider number of samples so that it is not limited. This research is expected to be a comparison and, at the same time, a reference in exploring the Science of Investment Management and Capital Markets, the period and type of investment that is the focus of research can vary, but the basis and framework of thinking in this research is expected to help academics to explore various kinds of problems investment-related. Meanwhile, it is very important for investment actors to 
pay attention to the assessment of financial performance, which is very important to determine the performance of investment instruments.

\section{Acknowledgment}

I thank those who have helped me in making this journal.

\section{References}

Bareksa. (2019, Juni 12). Know The Sharpe, Treynor And Jensen Ratios In Measuring Mutual Fund Performance. Retrieved Mei 1, 2021, From Www.Bareksa.Com: Https:/Www.Bareksa.Com/Berita/Reksa-Dana/2019-06-12/Mengenal-Rasio-SharpeTreynor-Dan-Jensen-Dalam-Mengukur-Kinerja-Reksadana

Bareksa. (2021, Mei 05). Kemenkeu : Ekonomi Q1 Hanya 2,97 Persen Akibat Corona, Urgensi Bansos Meningkat. Retrieved Mei 1, 2021, From Www.Bareksa.Com: Https://Www.Bareksa.Com/Berita/Id/Text/2020/05/05/Kemenkeu-Ekonomi-Q1-Hanya-297Persen-Akibat-Corona-Urgensi-Bansos-Meningkat/24908/News

BKPM. (2021, April 26). Realisasi Investasi Triwulan I Tahun 2021 Rp 219,7 Triliun, Kepala BKPM Optimis Target Investasi Tercapai. Retrieved Mei Sabtu, 2021, From Https://Www.Bkpm.Go.Id: Https://Www.Bkpm.Go.Id/Id/Publikasi/SiaranPers/Readmore/2420901/71101

Iqbal, M. H. (2013). Research Data Analysis With Statistics 2nd Edition. Jakarta: Bumi Aksara.

Lestari, W. R. (2015). Performance Of Shariaequity Mutual Funds And Conventional Equity Mutual Funds. Jounal Of Master Of Management, Vol. 01, No 1.

Malik, A. (2021, Maret 19). Ini Yang Membedakan Antara Reksadana Syariah Dengan Konvensional. Retrieved Juni 20, 2021, From Www.Bareksa.Com:

Https://Www.Bareksa.Com/Berita/Reksa-Dana/2021-03-19/Ini-Yang-Membedakan-AntaraReksadana-Syariah-Dengan-Konvensional

Mustofa, N. H. (2017). Nasution. Investmen In The Shariacapital Marketing. Jakarta: Prenada Media Group.

Nur Kholidah, M. R. (2019). Performance Analysis Of Sharia Equity Mutual Funds Using The Sharpe,Treynor,Jensen,M And Methods. Indonesian Interdisciplinary Journal Of Sharia Economics (IIJSE), Vol 1 No . E-ISSN:2621-606X.

Reksoatmodjo, R. N. (2019). Statistics For Psychology And Education. Bandung: PT. Refika Aditama.

Sugiyono. (2014). Quantitative,Qualitative Anda Rnd Research Methods,20th Edition. Bandung: Alfabet

Tandelilin, E. (2011). Portofolio And Investmen Theory And Application. Yogyakarta: Kanisius. 